\title{
Retrospective analysis of retrograd intrarenal surgery results and factors affecting success rate
}

\section{Retrograd intrarenal cerrahi sonuçlarının retrospektif analizi ve başarı oranını etkileyen}

\author{
Alper Eken*, Bülent Soyupak*
}

*Acıbadem Adana Hastanesi Üroloji Kliniği, Adana

\begin{abstract}
Purpose:We evaluated predictive factors for the successful retrograd intrarenal surgery by retrospectively scrutinizing patients treated with retrograde intrarenal surgery.

Materials and methods: Records of 76 renal stone patients treated between April 2014 and November 2016 were analyzed. The medical history of the patients including laboratory and radiological findings as well as preoperative and postoperative data was analyzed.

Results: The mean age was $42.9 \pm 13.4$ years. The mean stone number was $1.84 \pm 0.92$ (total 135 stones). The mean stone size was $10.7 \pm 3.6 \mathrm{~mm}$, and cumulative stone burden was $121.8 \pm 83.7 \mathrm{~mm}^{2}$. There were a total of 135 stones: 8 of them located in the upper calyx, 25 in middle calyx, 52 lower calyx, 26 in renal pelvis and 24 in the ureteropelvic junction. We controlled our stone-free rate with $\mathrm{CT}$ one month after the surgery. The success rate and complete stone-free rate was $77.6 \%$ after the first session. Eleven patients had insignificant residual fragments, but 5 patients had residual stone. The total stone number, stone size and cumulative stone burden were found to be significant in the success of the surgery. Major complications were urosepsis in one patient, hemorrhage requiring transfusion in one patient and ureteral trauma that recovered with DJ placement and no need for open surgery in one patient.

Conclusion: RIRS is an effective operation with high stone free rate and minimally invasive operation method with minimal morbidity and complication rate. Stone number, stone size and cumulative stone burden are found to be main factors affecting success rate of the procedure.
\end{abstract}

Pam Med J 2018;11(1):49-55

Key words:Kidney stone, flexible ureterorenoscopy, retrograde intrarenal surgery, ureteroscopy

Özet

Amaç:Böbrek taşı nedeniyle retrograd intrarenal cerrahi uygulanan vakaların sonuçlarının ve operasyon başarısını etkileyen faktörlerin retrospektif olarak değerlendirilmesi amaçlandı.

Gereç ve yöntem: Nisan 2014 ile Kasım 2016 tarihleri arasında böbrek taşı tanısı alan ve retrograd intrarenal cerrahi yapılan 76 hasta çalışmaya alındı. Hastaların demografik özellikleri, taş lokalizasyonu, taş adeti, taş büyüklüğü, toplam taş yükü kaydedildi. Ameliyat öncesi ve sonrası veriler değerlendirildi.

Bulgular: Hastaların ortalama yaşı $42.9 \pm 13.4$ yıl idi. Hastaların $35^{\prime}$ inde sağ, $38^{\prime}$ inde sol böbrek taşı ve üç hastada ise her iki böbrekte taş vardı. Taş sayısı ortalama 1.84 0.92 hesaplandı (toplam 135 adet taş). Ortalama taş büyüklüğü $10.7 \pm 3.6 \mathrm{~mm}$ ve kümülatif taş yükü $121.8 \pm 83.7 \mathrm{~mm}^{2}$ olarak hesaplandı. Toplam taşların $8^{\prime} i$ üst kaliks, 25 'i orta kaliks, 52'si alt kaliks, 26 'si renal pelvis ve 24 'ü üreteropelvik yerleşimli idi. Operasyondan bir ay sonra taşsızlık oranının belirlenmesi amacıyla bilgisayarlı tomografi çekildi. Birinci seans sonunda hastaların $\% 77.6^{\prime}$ sında taşsızlık saptanırken, 11 hastada (\%14.5) 3mm'den küçük klinik önemsiz taş olduğu ve 5 hastada rezidü taş olduğu görüldü. Toplam taş sayısı, taş boyutu ve taş yükünün taşsızlık başarı şansını etkilediği görüldü. Operasyona bağlı bir hastada çoklu antibiyoterapi kullanmayı gerektiren ürosepsis, bir hastada kan transfüzyonu gerektirecek hemoraji ve bir hastada double $\mathrm{J}$ kateter ile düzelen üreteral travma majör komplikasyonlarımız idi. Sonuç: Retrograd intrarenal cerrahi böbrek taşlarının tedavisinde düşük morbidite ve yüksek başarı oranı ile uygulanabilen minimal invaziv bir yöntemdir. Toplam taş sayısı, taş boyutu ve taş yükünü retrograd intrarenal cerrahi başarı oranlarını etkileyen ana faktörlerdir.

Pam Tıp Derg 2018;11(1):49-55

Anahtar sözcükler:Böbrek taşı, fleksible üreterorenoskopi, retrograd intrarenal cerrahi, üreteroskopi

\author{
Alper Eken \\ Yazışma Adresi: Acıbadem Adana Hastanesi Üroloji Kliniği, Adana. \\ e-mail: alpereken@yahoo.com
}

Gönderilme tarihi: 27.04.2017 Kabul tarihi: 17.06.2017 


\section{Introduction}

The rapid increase in urinary stone disease causes clinical and economic burden for healthcare system across the world. International epidemiological data shows a marked increase in the prevalence of urinary stone disease. Nutrition habits, geographical region especially air temperature, genetic factors, body mass index and daily fluid intake plays role in urinary system stone etiology [1]. Turney et al. reported a dramatic economic cost on the healthcare system [2]. The treatment of urinary stone disease has been progressed in recent years with advances in medical sciences. Flexible ureteroscopes are most recent and leading improvement in the endourological field. They allow surgeons for easier reach to the upper urinary tract. This deflection capacity allows physicians to reach the entire kidney.

Current strategies to manage kidney stone focuses on minimally invasive techniques including extracorporal shockwave lithotripsy (ESWL), percutaneous nephrolithotomy (PCNL), laparoscopic surgery and retrograde intrarenal surgery (RIRS). The success rate of RIRS have been increased by improvements in medical instruments such as flexible ureteroscopy and laser lithotripsy. The success rate of RIRS is $50 \%$ to $94.2 \%$ [3-7]. The stone-free rate of RIRS is affected by some factors, and for urinary stone disease, RIRS needs more definite evidences to be a first-line treatment. Compared to the other minimally invasive procedures RIRS can be a successful alternative, but we need to understand the factors affecting its success. In this study, we retrospectively reviewed cases with RIRS to evaluate the factors that affect its success rate in the treatment of urinary stones.

\section{Material-Method}

This research used a retrospective study design. We evaluated the medical records and radiological exams of 76 patients who experienced retrograde intrarenal surgery for the treatment of urinary stones from April 2014 to November 2016. The characteristics of the urinary stones such as laterality of the stone as well as location, size, total number and total stone burden were evaluated from preoperative imaging studies. The mean cumulative stone burden was calculated by measuring the size of the individual stone in each patient. The stone burden is the product of longest diameter and the perpendicular diameter of the stone [8]. If there is more than one stone, then the volumes are added. The patients were classified according to their overall health condition into ASA scores (I-III). Patient with a normal healthy condition was placed in ASA I. Patients with the mild systemic disease are ASA II, and patients with the severe systemic disease are ASA III [9]. Preoperatively, previous kidney interventions like ESWL, PCNL, and open surgery were assessed.

Each surgery was performed under general anesthesia in the dorsal lithotomy position. After visualization of the bladder, a hydrophilic glide wire was inserted under fluoroscopy guidance. A 11-13 access sheath was placed when needed. All procedures were performed using Storz Flex-XC (Karl Storz Endoscope, Germany). A holmium-YAG laser with 200 or $365 \mu \mathrm{m}$ fiber was used to perform stone fragmentation in the patients. A N-Gage nitinol stone extractor (Cook Medical, USA ) was used to extract the fragmented stones. Double $J$ ureteral stent was placed in all patients at the end of RIRS procedure, and the removal time of DJ stent was noted. The postoperative follow-up studies were analyzed postoperatively and at 30 days post-surgery.

Although ultrasonography is easy to use and has no radiation risk, it has less sensitivity and specificity than computerized tomography. Therefore, a radiological control used CT. In this study, the success rate was defined as the complete absence of any fragment of stone on postoperative studies and the residual stones of less than $3 \mathrm{~mm}$ in the postoperative analysis. The secondary outcomes were major complications due to RIRS surgery.

All data were analyzed with standard statistical software, SPSS v. 20.0 (SPSS Inc., Chicago, IL, USA). Student's t-test and one-way ANOVA were performed to find the statistically significant relationship between the variables of urinary stones; $p<0.05$ was considered statistically significant. The study was performed in compliance with ethical principles of the World Medical Association Declaration of Helsinki. The study was approved by the institutional review board (IRB). Waiver of consent was obtained since the study involved the analysis of existing medical records. 


\section{Results}

Table 1 shows the demographic and preoperative characteristics of the study. In this study, 76 patients who underwent RIRS were analyzed. Of these 76 patients, 61 were male and 15 were female. The age ranged from 4-77 years. The mean age of the patients was $42.9 \pm 13.4$ years. The BMI of the patients ranged from 14.8-52.7 with a mean BMI of 28.5 \pm 5.94 . A total of 38 patients had left laterality, and 3 had bilateral stones. The 76 patients had 135 stones. We had three renal anomalias: one horseshoe kidney, one solitary kidney and one double collecting system. The mean size of the stones was $10.7 \pm 3.6 \mathrm{~mm}$. The cumulative stone burden was $121.8 \pm 83.7 \mathrm{~mm}^{2}$. In most patients $(n=52)$, the location of the stone was the middle calyx. 55 patients $(72.4 \%)$ had no previous kidney intervention. Of all the patients 8 of them had ESWL, 9 of them had PCNL and 4 of the patients had open surgery.

Dilatation of ureteral orifice was performed in 35 patients. A ureteral access sheath was replaced in 47 patients $(61.8 \%)$. The mean operation time was $67.9 \pm 28.4$ minutes. The length of hospital duration was $30.1 \pm 56.8$ hours. The average time needed to remove the postoperative placed Double $\mathrm{J}$ stent was 15.3 \pm 16.6 days. A complete stone-free rate was found in $77.6 \%$ of 59 patients after RIRS. Twelve patients had insignificant residual fragments smaller than $3 \mathrm{~mm}$; residual fragments were seen in $6.6 \%$ (5 patients)

Major complications in this study were urosepsis in one patient,hemorrhage requiring transfusion in one patient, and ureteral trauma solved via DJ placement in one patient. Urosepsis occurred in a neonatal hypoxic ischemic encephalopathy patient

Table 1. Demographics and preoperative characteristics

\begin{tabular}{|c|c|}
\hline Variables & Frequency \\
\hline No. of Patients & 76 \\
\hline Mean Age & $42.9 \pm 13.4$ \\
\hline Mean BMI & $28.5 \pm 5.94$ \\
\hline \multicolumn{2}{|l|}{ Sex } \\
\hline Male & 61 \\
\hline Female & 15 \\
\hline \multicolumn{2}{|l|}{ Laterality } \\
\hline Right & 35 \\
\hline Left & 38 \\
\hline Bilateral & 3 \\
\hline Mean Stone Size (mm) & $10.7 \pm 3.6 \mathrm{~mm}$ \\
\hline Cumulative stone burden $\left(\mathrm{mm}^{2}\right)$ Mean & $121.8 \pm 83.7$ \\
\hline Mean Stone Number (Mean) & $1.84 \pm 0.92(1-5)$ \\
\hline Single & 36 \\
\hline Double & 22 \\
\hline Others & 18 \\
\hline \multicolumn{2}{|l|}{ ASA criteria } \\
\hline ASA I & 39 \\
\hline ASA II & 24 \\
\hline ASA III & 22 \\
\hline \multicolumn{2}{|l|}{ Stone Location } \\
\hline Upper Calyx & 8 \\
\hline Lower Calyx & 25 \\
\hline Middle Calyx & 52 \\
\hline Renal Pelvic & 26 \\
\hline Uretopelvic & 24 \\
\hline
\end{tabular}


with a horseshoe kidney. The patients' total stone burden was $429 \mathrm{~mm}^{2}$. This patient was treated with double intravenous antibiotics and discharged on the $13^{\text {th }}$ day after surgery. Hemorrhage requiring transfusion occurred in a 71-year-old male patient; his ASA score was III due to alcohol-related chronic liver disease with known bleeding tendency. He was discharged 12 days after the surgery. Other complications included fever in 6 patients that was solved with oral antibiotics plus an antipyretic and postoperative pain (VAS $>5$ ) in 3 patients that was solved with opioid analgesics and discharge with nonsteroidal anti-inflammatory drugs.

Our analysis showed that the predictive factors for complete stone free or success rate of RIRS were the stone number, mean stone size and total stone burden (Table 2). While the total stone number in the stone-free group was 1.53, it was 2.8 in the residual group. Similarly, the mean stone size and total stone burden were much higher in the non-significant residual and residual group compared to the completely stone-free group $(p<0.05)$. In subgroup analysis, access sheath placement, intraoperative dilatation of ureteral orifice or previous DJ stenting does not affect success rate. In addition, the stone free rate affects DJ catheter removal time and hospitalization time. This is relevant to the complications.

\section{Discussion}

RIRS is a minimally invasive procedure that is efficient in the treatment of urinary stones across all age groups. Recent advancements in medical sciences and the invention of improved instruments for intracorporeal lithotripsy and flexible URS make retrograde intrarenal surgery successful.

Despite the high success rate of retrograde intrarenal surgery, certain factors are critical for its success. Success rates and complications from RIRS were described in a prospective multicenter European study from Berardinelli et al [10]. From 2012 to 2014, they evaluated 377 patients. The mean operation time was 63.5 minutes, and the stone size was $12.4 \mathrm{~mm}$. After the first session, they achieved a $73.6 \%$ stonefree rate. Subgroup analysis indicated a $68.9 \%$ success rate from lower pole calyx stones and $77.4 \%$ for the sheathless procedure. Hussein et al. proposed an upper stone limit of $2 \mathrm{~cm}$ that can be predict single session success [7]. This was further confirmed in Aboumarzouk et al [11].

Javanmard and coworkers also studied renal stones smaller than $2 \mathrm{~cm}$ [12]. They compared outcomes of RIRS with ESWL for stones smaller than $2 \mathrm{~cm}$ (mean $16.8 \mathrm{~mm}$ ) in 2016. The single session success rate in the RIRS group was $90 \%$ with a mean 79.9 minutes operation time. Although RIRS effectiveness was studied in cases smaller than $2 \mathrm{~cm}$, Akman et al. reviewed the RIRS results for 2-4 cm kidney stones [13]. The mean operative time was 58.2 minutes, and the stone-free rate after one session was $73.9 \%$. In our study, the mean stone size was $10.7 \mathrm{~mm}$. With insignificant residual fragments, the total success rate increased to $92.3 \%$. In our opinion, the biggest reason for this single session success is related to the stone size.

Similarly, the cumulative stone burden was found to be $121.8 \pm 83.7 \mathrm{~mm}^{2}$, which is low relative to previous studies $(168.9 \pm 392.5)$ [4].

Table 2. Analysis of the variables

\begin{tabular}{lllll}
\hline Variables & Stone free & $\begin{array}{l}\text { Insignificant Residual } \\
\text { Fragments }\end{array}$ & Residual fragments & p value \\
\hline Age & $41.1 \pm 11.8$ & $46.3 \pm 17.7$ & $54 \pm 15.9$ & 0.08 \\
BMI & $27.2 \pm 5$ & $31.2 \pm 8.5$ & $29.4 \pm 10.1$ & 0.28 \\
Stone Number & $1.53 \pm 0.6$ & $2.2 \pm 1.4$ & $2.8 \pm 1.3$ & $<0.05$ \\
Mean stone size & $9.7 \pm 2.6$ & $10.9 \pm 2.8$ & $13.6 \pm 4.7$ & $<0.05$ \\
Total stone burden & $94.2 \pm 36.1$ & $185 \pm 130.6$ & $231.6 \pm 143$ & $<0.05$ \\
$\begin{array}{l}\text { Operation time } \\
\text { Removal of DJ }\end{array}$ & $64.8 \pm 26.1$ & $68,2 \pm 16.3$ & $79 \pm 31.1$ & 0.73 \\
catheter & $11.4 \pm 13.2$ & $28.1 \pm 22.7$ & $35.2 \pm 31.7$ & $<0.05$ \\
\hline
\end{tabular}

BMI: Body Mass Index, DJ: Double J 
Elbir et al.[14]reviewed 279 flexible ureteroscopy results. Their median stone diameter was $13.5 \mathrm{~mm}$ with stone-free rates of $78.4 \%$. They emphasized that success rate decreases as stone diameter increases. While the success rate was $84.4 \%$ for stones $<1 \mathrm{~cm}$, it was $60 \%$ for stones bigger than $2 \mathrm{~cm}$. Similarly, we found that a high stone burden affects the success rate. Age and gender does not affect the success rate.

In 2012, Resorlu et al.[15] reviewed 207 patients. They examined factors that may affect success rates in flexible ureterorenoscopy. Again, they found that stone size, stone location and the infundibulopelvic angle of the lower calyx affects the success rate. They also evaluated stone composition and renal malformations and found both that this two factor may affect the success rate. We did not evaluate stone composition because holmium: YAG laser lithotripsy is effective for all stone compositions, and it fragments all of the stones.

In our study, the mean operation time was $67.9 \pm 28.4$ minutes which is short compared to previous studies. This might be because the stones were smaller in this cohort. Postoperative DJ stenting is required mainly to relieve urinary passage according to ureteral edema and pain. In Berardinelli et al. [10], postoperative DJ placement was $93 \%$. Here, all patients received a DJ stent. Some of them were extracted after three days, but the mean removal time was $15.3 \pm 16.6$ days. Another study reported 11.2 \pm 3.5 days [14]. These differences are mostly due to surgeon preference.

Intraoperatively access sheath placement remains controversial. Some authors suggest routine placement due to advantages like decreased operation time, lower intrapelvic pressure and minimal morbidity $[16,17]$. Other authors do not recommend access sheaths due to possible ureteral injury [18]. Traxer et al. in particular showed that approximately half of the access sheath placed patients had different degrees of ureteral injury [19]. In our study, intraoperative access sheath placement was $61.8 \%$ (47 patients). The subgroup analysis showed no significant differences between the placed and non-placed group according to the stone free rate.
Oguz et al.[20] used renal malrotation and Molimard et al.[21] used horseshoe kidneys to review their experience. Both studies showed that retrograde intrarenal surgery is effective in renal anomalias. Gokce et al. [22] compared the efficacy of ESWL and RIRS in horseshoe kidneys in 2016. In their study, the stone-free rate of RIRS was $73.9 \%$. They stated that RIRS is an effective method for horseshoe kidney patients. In contrast, we have only one patient with horseshoe kidney, one right solitary kidney and one with a double collecting system. The patient with horseshoe kidney had postoperative residual fragments. With only one patient, we cannot state whether renal anomalia affects the success rate.

The other factor that may affect the outcome is previous kidney intervention. In 2015, Alkan et al. [23] retrospectively examined 32 patients who underwent RIRS and who had previous open renal surgery history. The mean stone size was $10.1 \mathrm{~mm}$, and they compared outcomes to a control group with no previous renal surgery. They found no difference between two groups. Similarly, none of our 55 patients had previous kidney interventions, but 8 had ESWL, 9 had PNL and 4 had open surgery. One of the patients had both PNL and open surgery history. There was no difference in terms of success rate between those with a previous kidney intervention and those that did not.

Retrograd intrarenal surgery has lower complication rates. Postoperative urinary tract infection can generally be solved with oral antibiotics. Like other interventions, RIRS should done after sterilization of the urine as verified by urine analysis and urine culture. Berardinelli et al. [10] found an overall complication rate of $15.1 \%$. Their complications included minor ureteral wall injuries that were easily managed with DJ catheter placement (3\%), postoperative fever managed with antipyretics $(6.4 \%)$, and pyelonephritis $(0.5 \%)$. In our study, we found 6 subjects with postoperative fever on the first day and discharged with oral ciprofloxacin (Clavien Dindo classification - grade 2) [24]. Only one patient had urosepsis that required intravenous antibiotics (Grade 4a complication). This complication occurred in a horseshoe kidney with a high stone burden. His urine was sterile when we planned the operation but calyxcealinfected urine was seen intraoperatively. 
Though we terminated the operation after DJ stent placement, he had a serious infection and required double IV antibiotics.

Another serious complicat ion is bleeding that requires transfusion. In 2002, Watterson et al.[25] studied flexible ureterorenoscopy in patients with bleeding diathesis and patients on anticoagulant therapy. Their success rate was $96 \%$ with only one retroperitoneal hematoma that required blood transfusion. Similarly, a systematic review in 2012 emphasized RIRS as an alternative for ESWL and PNL and an effective tool in bleeding diathesis or anticoagulant use [26]. We found no retroperitoneal hematoma but severe hematuria that required erythrocyte and thrombocyte suspension transfusion (Grade 2 complication). However, we think that it is related to severe bleeding tendencies due to alcoholic chronic liver disease in the patient. Javanmard et al.[12] found a postoperative mean of VAS $3.1 \pm 2.7$ and a ESWL lower than 5.2 \pm 2.8 . They specified a need for fewer analgesics. Similarly, postoperative pain (VAS $>5$ ) was described in our study from only 3 patients (Grade 2 complication). This was solved with opioid analgesics. Subjects were discharged on the first postoperative day. This study is limited by the number of patients and its retrospective design.

In conclusion, RIRS is an effective and minimally invasive procedure for the treatment of renal stones. Higher stone-free rates with less complication is achieved by by advances in endourological field. Higher stone-free rates may be provided by starting with small sizes and smaller number of stones.

Conflict of interest statement: The authors declare no conflict of interest.

\section{References}

1. Romero V, Akpinar H, Assimos DG. Kidney stones: a global picture of prevalence, incidence, and associated risk factors. Rev Urol 2010;12:e86-96.

2. Turney BW, Reynard JM, Noble JG, Keoghane SR. Trends in urological stone disease. BJU Int 2012;109:1082-1087.

3. Süer E, Gülpinar Ö, Özcan C, Göğüş Ç, Kerimov S, Şafak M. Predictive factors for flexible ureterorenoscopy requirement after rigid ureterorenoscopy in cases with renal pelvic stones sized 1 to $2 \mathrm{~cm}$. Korean $\mathrm{J}$ Urol 2015;56:138-142.
4. Lim SH, Jeong BC, Seo SI, Jeon SS, Han DH. Treatment outcomes of retrograde intrarenal surgery for renal stones and predictive factors of stone-free. Korean J Urol 2010;51:777-782.

5. Unsal A, Resorlu B. Retrograde intrarenal surgery in infants and preschool-age children. J Pediatr Surg 2011;46:2195-2199.

6. Perlmutter AE, Talug C, Tarry WF, Zaslau S, Mohseni $\mathrm{H}$, Kandzari SJ. Impact of stone location on success rates of endoscopic lithotripsy for nephrolithiasis. Urology 2008;71:214-217.

7. Hussain M, Acher P, Penev B, Cynk M. Redefining the limits of flexible ureterorenoscopy. J Endourol 2011;25:45-49.

8. Merigot de Treigny O, Bou Nasr E, Almont T, et al. The cumulated stone diameter: a limited tool for stone burden estimation. Urology 2015;86:477-481.

9. American Society of Anesthesiologist, avaible in web www.asahq.org/resources/clinical-information/asaphysical-status-classification-system.

10. Berardinelli F, Proietti S, Cindolo L, et al. A prospective multicenter European study on flexible ureterorenoscopy for the management of renal stone. Int Braz J Urol 2016:42;479-486.

11. Aboumarzouk OM, Monga M, Kata SG, Traxer O, Somani BK. Flexible ureteroscopy and laser lithotripsiy for stones $>2 \mathrm{~cm}$ : a systematic review and metaanalysis. J Endourol. 2012;26:1257-1263.

12. Javanmard B, Kashi AH, Mazloomfard MM, Ansari Jafari A, Arefanian S. Retrograd intrarenal surgery versus shock wave lithotripsy for renal stones smaller than $2 \mathrm{~cm}$ : a randomized clinical trial. Urol J 2016;13:2823-2828.

13. Akman $\mathrm{T}$, Binbay M, Ozgor F, et al. Comparison of percutaneous nephrolithotomy and retrograde flexible nephrolithotripsy for the management of 2-4 cm stones: a matched-pair analysis. BJU Int 2012;109:1384-1389.

14. Elbir F, Basibüyük I, Topaktaş R, et al. Flexible ureterorenoscopy results: analysis of 279 cases. Turk J Urol 2015;41:113-118.

15. Resorlu B, Unsal A, Gulec H, Oztuna D. A new scoring system for predicting stone-free rate after retrograde intrarenal surgery: the "resorlu-unsal stone score". Urology 2012;80:512-518.

16. Rapoport D, Perks AE, Teichman JM. Ureteral access sheath use and stenting in ureteroscopy: effect on unplanned emergency room visits and cost. J Endourol 2007;21:993-997.

17. Kourambas J, Byre RR, Preminger GM. Does a ureteral access sheath facilitate ureteroscopy? J Urol 2001;165:789-793.

18. Delvecchio FC, Auge BK, Brizuela RM, et al. Assessment of stricture formation with the ureteral access sheat. Urology 2003;61:518-522.

19. Traxer $O$, Thomas A. Prospective evaluation and classification of ureteral wall injuries resulting from insertion of a ureteral access sheath during retrograde intrarenal surgery. J Urol 2013;189:580-584. 
20. Oğuz U, Balci M, Atis G, et al. Retrograde intrarenal surgery in patients with isolated anomaly of kidney rotation. Urolithiasis 2014;42:141-147.

21. Molimard B, Al-Qahtani S, Lakmichi A, et al. Flexible ureterorenoscopy with holmium laser in horseshoe kidneys. Urology 2010;76:1334-1337.

22. Gokce MI, Tokatli Z, Suer E, Hajiyev P, Akinci A, Esen B. Comparison of shock wave lithotripsy (SWL) and retrograde intrarenal surgery (RIRS) for the treatment of stone disease in horseshoe kidney patients. Int Braz J Urol 2016;42:96-100.

23. Alkan E, Saribacak A, Ozkanli AO, Başar MM, Acar O, Balbay MD. Retrograde intrarenal surgery in patients who previously underwent open renal stone surgery. Minim Invasive Surg 2015;2015:198765.

24. Dindo D, Demartines N, Clavien PA. Classification of surgical complications. a new proposal with evaluation in a cohort of 6336 patients and results of a survey. Ann Surg 2004;240:205-213.

25. Watterson JD, Girvan AR, Cook AJ, et al. Safety and efficacy of holmium: YAG laser lithotripsy in patients with bleeding diatheses. J Urol 2002;168:442-445.

26. Abomarzouk OM, Somani BK, Monga M. Flexible ureteroscopy and holmium: YAG laser lithotripsy for stone disease in patients with bleeding diathesis: a systematic review of the literature. Int Braz J Urol 2012;38:298-305. 